A Textbook of Regional Anatomy 


\section{A Textbook of Regional Anatomy}

\section{J. Joseph, MD, DSc, FRCOG}

Professor of Anatomy, Guy's Hospital Medical School, London 
(C) J. Joseph 1982

Softcover reprint of the hordcover 1st edition 1982 978-0-333-28911-2

All rights reserved. No part of this publication may be reproduced or transmitted, in any form or by any means, without permission.

First published 1982 by

THE MACMILLAN PRESS LTD

London and Basingstoke

Companies and representatives

throughout the world

Typeset in 10/12pt Press Roman by

ILLUSTRATED ARTS

Sutton, Surrey

ISBN 978-0-333-28912-9 ISBN 978-1-349-16831-6 (eBook)

DOI 10.1007/978-1-349-16831-6

The paperback edition of the book is sold subject to the condition that it shall not, by way of trade or otherwise, be lent, resold, hired out, or otherwise circulated without the publisher's prior consent in any form of binding or cover other than that in which it is published and without a similar condition including this condition being imposed on the subsequent purchaser. 


\section{To my wife Carol and our twins Nicholas and Andrew}




\section{Contents}

Preface

xvii

Acknowledgements

xix

Anatomical Terminology

xxi

\section{PART 1: THE THORAX}

1 The Thoracic Skeleton and Walls $\quad 3$

The thoracic skeleton $\quad 3$

The thoracic vertebrae $\quad 3$

$\begin{array}{ll}\text { The ribs } & 7\end{array}$

$\begin{array}{ll}\text { The sternum (breast bone) } & 8\end{array}$

$\begin{array}{ll}\text { The radiology of the thoracic vertebrae } & 8\end{array}$

$\begin{array}{ll}\text { The thoracic walls } & 9\end{array}$

The skeletal surface markings $\quad 9$

$\begin{array}{ll}\text { The skin } & 10\end{array}$

$\begin{array}{ll}\text { The mammary gland (breast) } & 12\end{array}$

$\begin{array}{ll}\text { The muscles on the outside of the chest wall } & 14\end{array}$

$\begin{array}{ll}\text { The intercostal spaces } & 14\end{array}$

$\begin{array}{ll}\text { The diaphragm } & 17\end{array}$

$\begin{array}{ll}\text { The movements of respiration } & 19\end{array}$

2 The Contents of the Thorax I: The Lungs and Heart $\quad 22$

$\begin{array}{ll}\text { The arrangement of the contents } & 22\end{array}$

$\begin{array}{ll}\text { The pleura } & 22\end{array}$

$\begin{array}{ll}\text { The lungs } & 25\end{array}$

$\begin{array}{ll}\text { The heart } & 30\end{array}$

$\begin{array}{ll}\text { The pericardium } & 30\end{array}$

The position and external appearance of the heart $\quad 31$

The interior of the chambers of the heart $\quad 33$

$\begin{array}{ll}\text { The structure of the heart wall } & 36\end{array}$

The blood supply and venous drainage of the heart $\quad 37$

$\begin{array}{ll}\text { The conducting system of the heart } & 39\end{array}$

$\begin{array}{ll}\text { The nerve supply of the heart } & 40\end{array}$

$\begin{array}{ll}\text { The radiology of the heart and lungs } & 40\end{array}$ 


\section{viii $\quad$ A Textbook of Regional Anatomy}

3 The Contents of the Thorax II: The Remainder of the Mediastinum 45

The general arrangement of the structures $\quad 45$

$\begin{array}{ll}\text { The pulmonary trunk } & 45\end{array}$

$\begin{array}{ll}\text { The aorta } & 46\end{array}$

$\begin{array}{ll}\text { The veins } & 48\end{array}$

$\begin{array}{ll}\text { The nerves and nerve plexuses } & 49\end{array}$

$\begin{array}{ll}\text { The trachea, main bronchi and oesophagus } & 51\end{array}$

The thoracic duct and lymph nodes of the thorax $\quad 53$

$\begin{array}{ll}\text { The thymus } & 55\end{array}$

\section{PART 2: THE ABDOMEN}

4 The Abdominal Walls $\quad 59$

The lumbar vertebrae, sacrum, coccyx and hip bone $\quad 59$

The lumbar vertebrae $\quad 59$

$\begin{array}{ll}\text { The sacrum and coccyx } & 62\end{array}$

The hip bone $\quad 64$

The anterior abdominal wall $\quad 66$

$\begin{array}{ll}\text { The skin } & 66\end{array}$

$\begin{array}{ll}\text { The superficial fascia } & 68\end{array}$

The muscles of the anterior abdominal wall $\quad 69$

$\begin{array}{ll}\text { The fascia transversalis } & 73\end{array}$

$\begin{array}{ll}\text { The inguinal canal } & 73\end{array}$

$\begin{array}{ll}\text { Inguinal and other hernias } & 75\end{array}$

The blood vessels and lymphatic drainage of the anterior abdominal wall 76

5 The Peritoneum $\quad 77$

$\begin{array}{ll}\text { The arrangement of the peritoneum in a sagittal section } & 78\end{array}$

$\begin{array}{ll}\text { The arrangement of the peritoneum in transverse section } & 79\end{array}$

The ligaments and mesenteries of the peritoneum $\quad 79$

The peritoneal spaces and compartments $\quad 81$

6 The Abdominal Alimentary Tract $\quad 82$

The abdominal oesophagus $\quad 82$

$\begin{array}{ll}\text { The stomach } & 83\end{array}$

The coeliac trunk (artery) $\quad 85$

The small intestine $\quad 86$

$\begin{array}{ll}\text { The duodenum } & 86\end{array}$

$\begin{array}{ll}\text { The jejunum and ileum } & 88\end{array}$

The superior mesenteric artery and vein $\quad 89$

$\begin{array}{lr}\text { The large intestine } & 90\end{array}$

The ascending colon $\quad 92$

The inferior mesenteric artery and vein $\quad 94$

The lymphatic drainage and nerve supply of the small and large intestine 95

The radiology of the alimentary tract $\quad 95$

7 The Liver, Bile Passages, Pancreas and Spleen $\quad 97$

$\begin{array}{ll}\text { The liver } & 97\end{array}$ 
$\begin{array}{ll}\text { The bile passages } & 100\end{array}$

$\begin{array}{ll}\text { The pancreas } & 101\end{array}$

$\begin{array}{ll}\text { The spleen } & 102\end{array}$

$\begin{array}{ll}\text { The hepatic portal vein and its tributaries } & 104\end{array}$

8 The Posterior Abdominal Wall and Related Structures 106

$\begin{array}{ll}\text { The muscles and fascia } & 106\end{array}$

$\begin{array}{ll}\text { The kidneys, suprarenal glands and ureters } & 107\end{array}$

$\begin{array}{ll}\text { The kidneys } & 107\end{array}$

The suprarenal glands $\quad 111$

$\begin{array}{ll}\text { The ureter } & 111\end{array}$

The abdominal aorta, inferior vena cava, autonomic nerves and lymphatics $\quad 114$

The abdominal aorta $\quad 114$

The common iliac arteries and their branches $\quad 115$

The inferior vena cava and its tributaries $\quad 116$

$\begin{array}{ll}\text { The lumbar plexus of nerves } & 117\end{array}$

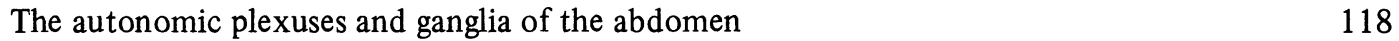

$\begin{array}{ll}\text { The lymph nodes of the abdomen } & 119\end{array}$

\section{PART 3: THE PELVIS AND PERINEUM}

9 The Pelvis

The pelvic bones, ligaments and joints $\quad 125$

Sex differences in the bony pelvis $\quad 129$

The obstetric pelvis $\quad 129$

$\begin{array}{lr}\text { The pelvic muscles and fascia } & 130\end{array}$

$\begin{array}{ll}\text { The pelvic peritoneum } & 132\end{array}$

10 The Pelvic Organs 134

The rectum and anal canal $\quad 134$

$\begin{array}{ll}\text { The urinary bladder } & 137\end{array}$

$\begin{array}{lr}\text { The ureter in the pelvis } & 140\end{array}$

The female pelvic genital organs $\quad 141$

$\begin{array}{ll}\text { The ovary } & 141\end{array}$

The uterine tube $\quad 142$

The uterus $\quad 143$

$\begin{array}{ll}\text { The vagina } & 148\end{array}$

$\begin{array}{lr}\text { The male pelvic genital organs } & 149\end{array}$

$\begin{array}{lr}\text { The ductus (vas) deferens } & 149\end{array}$

The seminal vesicle $\quad 150$

$\begin{array}{ll}\text { The prostate } & 150\end{array}$

11 The Pelvic Blood Vessels, Nerves and Lymph Nodes 151

The internal iliac artery and vein $\quad 151$

The sacral plexus of nerves $\quad 152$

The pelvic autonomic nerves and plexuses $\quad 153$

$\begin{array}{ll}\text { The pelvic lymph nodes } & 155\end{array}$ 


\section{x A Textbook of Regional Anatomy}

12 The Perineum, Including the External Genitalia 156

The anal triangle $\quad 156$

$\begin{array}{lr}\text { The ischiorectal fossa } & 156\end{array}$

$\begin{array}{lr}\text { The male external genitalia } & 157\end{array}$

$\begin{array}{ll}\text { The penis } & 157\end{array}$

The scrotum $\quad 158$

The testis and epididymis $\quad 159$

$\begin{array}{ll}\text { The urethra in the male } & 161\end{array}$

The urogenital triangle in the male $\quad 162$

$\begin{array}{ll}\text { The female external genitalia } & 165\end{array}$

The mons pubis, labia majora and labia minora $\quad 165$

$\begin{array}{ll}\text { The vestibule } & 165\end{array}$

$\begin{array}{ll}\text { The clitoris } & 166\end{array}$

The blood and nerve supply and lymphatic drainage of the female external genitalia $\quad 167$

$\begin{array}{ll}\text { The urethra in the female } & 168\end{array}$

The urogenital triangle in the female $\quad 168$

The tendinous centre of the perineum in the female

\section{PART 4: THE HEAD AND NECK}

13 The Skull and the Cervical Vertebrae 173

$\begin{array}{ll}\text { The skull } & 173\end{array}$

General 173

$\begin{array}{ll}\text { The anterior aspect of the skull } & 174\end{array}$

$\begin{array}{ll}\text { The lateral aspect of the skull } & 175\end{array}$

The posterior aspect of the skull $\quad 176$

$\begin{array}{ll}\text { The superior aspect of the skull } & 177\end{array}$

$\begin{array}{ll}\text { The inferior aspect of the skull } & 178\end{array}$

$\begin{array}{ll}\text { The mandible } & 180\end{array}$

The structure of the bones of the skull $\quad 182$

The ossification of the bones of the skull $\quad 182$

$\begin{array}{ll}\text { The growth of the skull } & 185\end{array}$

The cervical vertebrae $\quad 186$

14 The Scalp, Face and Parotid Gland $\quad 191$

$\begin{array}{ll}\text { Surface features } & 191\end{array}$

$\begin{array}{ll}\text { The arteries, nerves and veins of the face and scalp } & 191\end{array}$

The muscles of the face and scalp $\quad 194$

The nerve supply and functions of the muscles 196

$\begin{array}{ll}\text { The structure of the scalp } & 196\end{array}$

$\begin{array}{ll}\text { The parotid gland } & 198\end{array}$

15 The Temporomandibular Joint and Related Structures 200

$\begin{array}{ll}\text { The muscles of mastication } & 201\end{array}$

The temporomandibular joint $\quad 203$

$\begin{array}{ll}\text { The temporal fossa } & 205\end{array}$

$\begin{array}{ll}\text { The infratemporal fossa } & 205\end{array}$ 
$\begin{array}{ll}\text { The pterygopalatine fossa } & 205\end{array}$

The mandibular and maxillary nerves and maxillary vessels $\quad 205$

$\begin{array}{ll}\text { The mandibular nerve and otic ganglion } & 205\end{array}$

$\begin{array}{ll}\text { The maxillary nerve and pterygopalatine ganglion } & 208\end{array}$

$\begin{array}{ll}\text { The maxillary artery and vein } & 210\end{array}$

$\begin{array}{ll}16 \text { The Neck I } & 212\end{array}$

The skin and surface markings $\quad 212$

$\begin{array}{ll}\text { The hyoid bone } & 213\end{array}$

$\begin{array}{ll}\text { The superficial fascia } & 214\end{array}$

$\begin{array}{ll}\text { The deep fascia } & 214\end{array}$

The trapezius and sternocleidomastoid muscles $\quad 216$

$\begin{array}{ll}\text { The triangles of the neck } & 217\end{array}$

$\begin{array}{ll}\text { The anterior triangle } & 217\end{array}$

The posterior triangle (the lateral region of the neck) 223

17 The Neck II $\quad 229$

$\begin{array}{ll}\text { The prevertebral muscles and the first rib } & 229\end{array}$

$\begin{array}{ll}\text { The common carotid artery } & 231\end{array}$

$\begin{array}{ll}\text { The internal carotid artery } & 232\end{array}$

The external carotid artery and its branches $\quad 233$

$\begin{array}{ll}\text { The internal jugular vein } & 235\end{array}$

$\begin{array}{ll}\text { The cervical plexus } & 235\end{array}$

$\begin{array}{ll}\text { The glossopharyngeal nerve } & 236\end{array}$

$\begin{array}{ll}\text { The vagus nerve in the neck } & 237\end{array}$

$\begin{array}{ll}\text { The accessory nerve } & 238\end{array}$

$\begin{array}{ll}\text { The hypoglossal nerve } & 239\end{array}$

The cervical part of the sympathetic system $\quad 239$

$\begin{array}{ll}\text { The lymph nodes of the neck } & 241\end{array}$

18 The Cranial Cavity 243

The bony features $\quad 243$

The external features of the brain $\quad 246$

$\begin{array}{ll}\text { The meninges } & 250\end{array}$

The intracranial course of the cranial nerves $\quad 254$

$\begin{array}{ll}\text { The arteries in the cranial cavity } & 258\end{array}$

$\begin{array}{ll}\text { The intracranial veins and venous sinuses } & 260\end{array}$

$\begin{array}{ll}\text { The hypophysis cerebri (pituitary gland) } & 263\end{array}$

19 The Orbit and Ear $\quad 264$

$\begin{array}{ll}\text { The orbit } & 264\end{array}$

$\begin{array}{ll}\text { The bony walls of the orbit } & 264\end{array}$

The eyelids and lacrimal apparatus $\quad 265$

$\begin{array}{ll}\text { The eyeball } & 267\end{array}$

The muscles, fascia and ligaments $\quad 270$

$\begin{array}{ll}\text { The nerves of the orbit } & 272\end{array}$

The ophthalmic arteries and veins $\quad 275$

The ear 
$\begin{array}{ll}\text { The external ear } & 277\end{array}$

$\begin{array}{ll}\text { The middle ear (tympanic cavity) } & 280\end{array}$

$\begin{array}{ll}\text { The internal ear } & 282\end{array}$

20 The Oral Cavity and Palate 286

The lips, cheeks and vestibule of the mouth $\quad 286$

$\begin{array}{ll}\text { The tongue } & 287\end{array}$

$\begin{array}{ll}\text { The teeth } & 291\end{array}$

The palate $\quad 293$

$\begin{array}{ll}\text { The oral cavity proper } & 295\end{array}$

21 The External Nose, Nasal Cavity and Paranasal Air Sinuses 296

The maxilla, palatine and ethmoid bones and inferior concha 296

$\begin{array}{ll}\text { The external nose } & 299\end{array}$

$\begin{array}{lr}\text { The nasal cavity } & 299\end{array}$

$\begin{array}{ll}\text { The paranasal air sinuses } & 302\end{array}$

22 The Pharynx and Cervical Oesophagus $\quad 305$

$\begin{array}{ll}\text { The pharynx } & 305\end{array}$

$\begin{array}{ll}\text { The cervical oesophagus } & 310\end{array}$

$\begin{array}{ll}\text { Swallowing (deglutition) } & 311\end{array}$

23 The Larynx and Cervical Part of the Trachea 312

$\begin{array}{ll}\text { The larynx } & 312\end{array}$

$\begin{array}{ll}\text { The cervical part of the trachea } & 320\end{array}$

24 The Autonomic Nerves and Lymphatic Vessels of the Head and Neck 321

$\begin{array}{ll}\text { The sympathetic ganglia and their branches } & 321\end{array}$

$\begin{array}{ll}\text { The parasympathetic ganglia and their branches } & 321\end{array}$

The lymph nodes, lymphoid tissue and lymphatic drainage of the head and neck 322

\section{PART 5: THE VERTEBRAL COLUMN}

25 The Vertebral Column and Spinal Cord $\quad 325$

$\begin{array}{ll}\text { The vertebral column as a whole } & 325\end{array}$

$\begin{array}{ll}\text { The vertebral joints } & 327\end{array}$

$\begin{array}{ll}\text { The muscles of the vertebral column } & 330\end{array}$

The movements of the vertebral column

The contents of the vertebral canal $\quad 334$

$\begin{array}{ll}\text { Some further considerations } & 337\end{array}$

\section{PART 6: THE UPPER LIMB}

26 The Shoulder Region $\quad 341$

The pectoral girdle and humerus $\quad 341$

$\begin{array}{ll}\text { The clavicle } & 341\end{array}$

$\begin{array}{ll}\text { The scapula } & 342\end{array}$

$\begin{array}{ll}\text { The humerus } & 344\end{array}$ 
The skin and surface features of the shoulder region

The anterior and lateral muscles of the shoulder region

The posterior muscles of the shoulder region

27 The Axilla

The walls of the axilla

The axillary artery and vein

The brachial plexus

The axillary lymph nodes

28 The Joints of the Shoulder Region

The sternoclavicular joint

The acromioclavicular joint

The movements of the scapula on the chest wall

The glenohumeral (shoulder) joint

29 The Upper Arm and Forearm

The radius

The ulna

The skin and surface markings

The superficial veins

The upper arm

The anterior compartment

$\begin{array}{ll}\text { The posterior compartment } & 372\end{array}$

The forearm

The anterior muscles

The main blood vessels of the forearm

The nerves of the front of the forearm

30 The Elbow and Radio-ulnar Joints

The elbow joint

The radio-ulnar joints

$\begin{array}{ll}31 \text { The Wrist and Hand } & 389\end{array}$

$\begin{array}{ll}\text { The bones of the wrist and hand } & 389\end{array}$

$\begin{array}{ll}\text { The carpal bones (the carpus) } & 389\end{array}$

$\begin{array}{ll}\text { The metacarpal bones } & 391\end{array}$

$\begin{array}{ll}\text { The phalanges } & 392\end{array}$

The palmar aspect of the hand $\quad 392$

$\begin{array}{ll}\text { The skin } & 392\end{array}$

The palmar aponeurosis $\quad 394$

$\begin{array}{ll}\text { The superficial vessels and nerves } & 395\end{array}$

The thenar and hypothenar eminences $\quad 397$

The long flexor tendons and lumbrical muscles $\quad 398$

The deep vessels and nerves $\quad 399$

The deep muscles of the hand $\quad 399$ 
The fascial spaces of the hand

The synovial sheaths of the long flexor tendons $\quad 400$

The dorsum of the hand

The joints of the wrist and hand

The movements of the thumb

The movements of the remaining digits

32 The Venous and Lymphatic Drainage and Segmental Innervation of the Upper Limb

The venous drainage of the upper limb

The lymphatic drainage of the upper limb

The segmental innervation of the upper limb

\section{PART 7: THE LOWER LIMB}

33 The Hip Bone, Femur, Patella and Anterior, Medial and Lateral Aspects of the Thigh

The hip bone

The femur

The patella

The anterior, medial and lateral aspects of the thigh

The surface markings and skin

The superficial and deep fasciae

The femoral triangle

The adductor region

34 The Gluteal Region, Back of the Thigh and Popliteal Fossa

The gluteal region

The back of the thigh

The popliteal fossa

36 The Tibia, Fibula and Knee Joint

The tibia

The fibula

The knee joint

The surface anatomy of the region of the knee

37 The Leg and Foot

The skeleton of the foot

The surface features of the leg and foot

The skin of the leg and foot

The anterior and lateral regions of the leg and the dorsum of the foot 
The superficial muscles $\quad 467$

The deep muscles and related structures $\quad 468$

The retinacula and synovial sheaths of the ankle $\quad 470$

38 The Sole of the Foot $\quad 472$

The plantar aponeurosis $\quad 472$

The four layers of muscles of the sole $\quad 472$

$\begin{array}{ll}\text { The first layer of muscles } & 474\end{array}$

The second layer of muscles $\quad 474$

$\begin{array}{ll}\text { The third layer of muscles } & 474\end{array}$

$\begin{array}{ll}\text { The fourth layer of muscles } & 475\end{array}$

The nerves and vessels of the sole $\quad 475$

39 The Tibiofibular and Ankle Joints and the Joints of the Foot. The Arches of the Foot 477

$\begin{array}{ll}\text { The tibiofibular joints } & 477\end{array}$

The ankle (talocrural) joint $\quad 478$

The joints of the foot $\quad 480$

$\begin{array}{ll}\text { The joints associated with inversion and eversion } & 481\end{array}$

$\begin{array}{ll}\text { The metatarsophalangeal and interphalangeal joints } & 482\end{array}$

The arches of the foot $\quad 483$

40 The Venous and Lymphatic Drainage and Segmental Innervation of the Lower Limb 486

The venous drainage of the lower limb 486

The lymphatic drainage of the lower limb 486

The segmental innervation of the lower limb 486

41 Human Posture and Walking $\quad 489$

$\begin{array}{ll}\text { Posture } & 489\end{array}$

Locomotion $\quad 491$

$\begin{array}{ll}\text { Index } & 495\end{array}$ 


\section{Preface}

One must assume that some justification is required for another textbook on human anatomy. Two main reasons can be put forward. Because of the very large changes in the preclinical curriculum there have also been changes in the teaching of anatomy both quantitatively and qualitatively. The introduction of new subjects in many of the medical curricula (psychology and sociology for medical students, genetics and statistics) has resulted in the time spent on anatomy being reduced. Within anatomy itself the amount of time spent on dissection has been curtailed and other aspects of anatomy have claimed an increased proportion of the time spent on the subject. In spite of this it may be said that although other aspects of anatomy have increased in importance, for example cellular biology, experimental and comparative embryology, neuroanatomy, a corpus of knowledge about the topography of the human body together with ways of studying living gross anatomy remains an essential part of the basic knowledge of anyone studying medicine, or any other subject involving the examination and treatment of a human being. After all the changes, gross anatomy, together with some knowledge of osteology and surface and radiological anatomy, can be regarded as one limb of the many appendages which belong to the subject. Hence the first reason for writing another textbook - to give a medical student or doctor, in a fairly brief compass and within the limits of the time available, sufficient information to enable him or her to learn and understand the basic gross structure of the different regions of the body.

The second reason for writing this book was the encouragement by several people to put on record the experience of teaching the subject for more than 35 years. It is possible to make much of anatomy interesting, some of it easy to understand and remember, and a small part even amusing. It is regrettable that one cannot make the whole of anatomy all of these. However, it has been suggested that putting good teaching into written and pictorial form is nearly as important as publishing research. The author himself cannot say that his teaching is good. He must leave that to his students, and it is appreciated that good oral teaching does not necessarily make a good textbook. The reverse of what was said about Oliver Goldsmith may be true:

'Here lies Nolly Goldsmith, for shortness called Noll He wrote like an angel and talk'd like poor Poll'

(David Garrick, impromptu epitaph)

Modern educationalists say that examinations should be an extension of teaching. They seldom approve of the corollary that teaching should be based on examinations. In fact it is often claimed that teaching should have no relationship to examinations, but since examinations are there, students are inevitably interested in them. Broadly speaking this book, except for some of the clinical applications, contains much of what most examiners expect students to learn during a course in topographical anatomy, and hence what 


\section{xviii $A$ Textbook of Regional Anatomy}

they require for their examinations, written or oral. They are, however, not expected to know everything in this book. It must be added that it is assumed that courses in cellular biology (histology, microscopic anatomy), embryology and neuro-anatomy, together with some lectures on general topics, form other parts of the anatomical curriculum. Reference to these aspects of anatomy are therefore incidental to the main description of the regional anatomy of the body.

It is hoped that the different subdivisions of anatomy are integrated so that students are learning the gross anatomy of a part of the body at the same time as they are learning its microscopic structure and development. Integration between the different preclinical departments, and with clinical medicine is also a feature of some medical schools. Whatever the organization of the curriculum, a knowledge of gross anatomy is a basic essential of medical education. Its importance in the past may have been overestimated but attempts to eliminate it have resulted in its being quickly restored as one of the pillars of a sound medical curriculum. 


\section{Acknowledgements}

Very few books are the result of one person's efforts. It gives me great pleasure to thank Frank Price (thorax), Paul Darton (abdomen and pelvis), Bridget Hough (head and neck) and Anne Barrett (limbs) for their drawings. I am very grateful to Kevin Fitzpatrick (photography), Department of Anatomy, and Jerry Rytina (teproductions of X-rays), Department of Medical Illustration, both of Guy's Hospital Medical School, for their substantial contribution to the illustrations. The publishers and editors of Hamilton's Textbook of Human Anatomy have very kindly given permission for the reproduction of a number of illustrations from that book, and I would like to thank Dr John Keishishian for permission to reproduce figure 148.

I owe a great debt to Margaret Collins for her typing, and retyping, the text and to Elizabeth Horne and The Macmillan Press for their encouragement and co-operation. Thanks are due to them, to Drs Sue Standring and Michael Hutchinson of the Department of Anatomy, Guy's Hospital Medical School, for their reading the manuscript and making many corrections and helpful suggestions and to Dr Nigel Bickerton for reading the page proofs and noticing all the errors which I overlooked. 


\section{Anatomical Terminology}

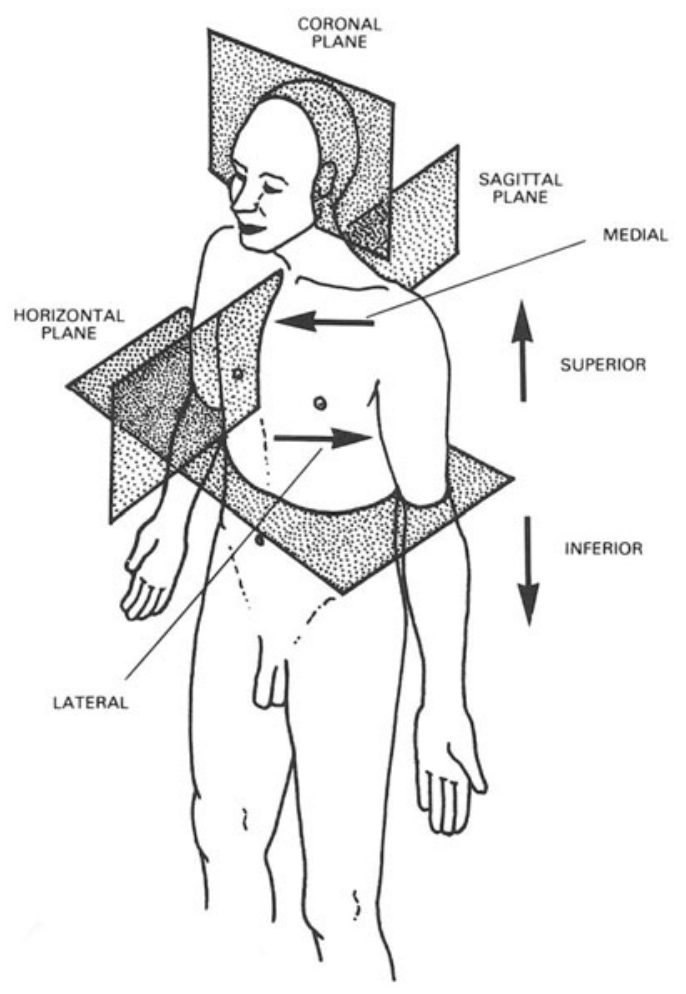

Figure 1 The anatomical position and some common anatomical terms.

In order to facilitate the description of parts of the body and to relate accurately one part to another, a standard position of the body is used. This is the anatomical position (figure 1) in which the body is erect with the head facing forwards, the upper limbs are at the sides of the trunk with the thumb pointing outwards, and the lower limbs are together and parallel to each other with the feet pointing forwards. In all relations between structures, the body is assumed to be in the erect position. 
The three cardinal planes which are used are the sagittal (sagitta $=$ arrow, Latin), a vertical plane in the midline running anteroposteriorly, the coronal (frontal) (corona $=$ crown, Latin), a vertical plane at right angles to the sagittal and the horizontal (transverse) running at right angles to the other two. The sagittal plane is often called the median and parasagittal planes are parallel to the sagittal. All vertical planes at right angles to the sagittal are called coronal.

The front surface of the body is anterior (ventral) and the back surface is posterior (dorsal). (In biology the term anterior means nearer the head.) These terms are also used to describe relative positions of parts of the body to one another, as are the terms medial and lateral which refer to the midline. The former is nearer the midline; the latter is further away from the midline. For example, in the anatomical position the index finger is medial to the thumb and the thumb is lateral to the index finger. Vertical relationships are indicated by the terms superior and inferior. For example, the head is superior to the neck. Cephalad (nearer the head; cephale $=$ head, Greek), cranial and rostral (nearer the beak; rostrum = beak, Latin) are synonyms for superior, and caudal (nearer the tail; cauda = tail, Latin) is synonymous with inferior. The terms superficial (nearer the surface) and deep (nearer the inside) refer to the surface of the body on any of its aspects. External and internal have similar meanings but refer especially to cavities or hollow organs. In the limbs a proximal structure is nearer the trunk and a distal structure is nearer the fingers or toes.

There are some common terms used for movements. Flexion is a forward movement about a transverse axis in the sagittal plane and extension is a backward movement about the same axis. Abduction is a movement about an anteroposterior axis in the coronal plane away from the midline of the body, and adduction is a movement towards the midline about the same axis. Many special terms are used to describe movements at various joints, such as pronation and supination of the forearm.

In general the terms used in this book are the accepted English translations of or the most recently revised version of the Nomina Anatomica. Frequently terms are translated or explained and common alternative terms, even if eponymous, are given, together with the dates, country and speciality of the individual after which a structure has been named. If it is thought that the first reference to a structure requires further explanation, more information is given, for example a spinal nerve or the term anastomosis. 